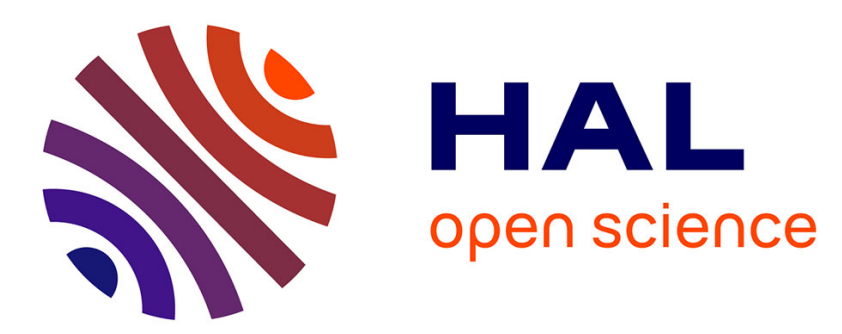

\title{
Human Pulp Fibroblast Implication in Phagocytosis via Complement Activation
}

Chloé Le Fournis, Christina Hadjichristou, Charlotte Jeanneau, Imad About

\section{To cite this version:}

Chloé Le Fournis, Christina Hadjichristou, Charlotte Jeanneau, Imad About. Human Pulp Fibroblast Implication in Phagocytosis via Complement Activation. Journal of Endodontics, 2019, 45 (5), pp.584590. 10.1016/j.joen.2018.10.023 . hal-02185275

\section{HAL Id: hal-02185275 \\ https://hal-amu.archives-ouvertes.fr/hal-02185275}

Submitted on 16 Jul 2019

HAL is a multi-disciplinary open access archive for the deposit and dissemination of scientific research documents, whether they are published or not. The documents may come from teaching and research institutions in France or abroad, or from public or private research centers.
L'archive ouverte pluridisciplinaire HAL, est destinée au dépôt et à la diffusion de documents scientifiques de niveau recherche, publiés ou non, émanant des établissements d'enseignement et de recherche français ou étrangers, des laboratoires publics ou privés. 


\title{
Human Pulp Fibroblast Implication in Phagocytosis via Complement Activation
}

\author{
Chloé Le Fournis, MSc, ${ }^{*}$ Christina Hadjichristou, MSc, ${ }^{\dagger}$ Charlotte Jeanneau, PbD, * \\ and Imad About, PbD*
}

\begin{abstract}
Ahstract
Introduction: Previous works have shown that human pulp fibroblasts synthetize all complement components. Local complement activation in the dental pulp is known to be involved in inflammation and regeneration and also in pathogen destruction through membrane attack complex formation. Bacterial elimination by complement-mediated phagocytosis implies microorganism opsonization with the complement $\mathrm{C} 3 \mathrm{~b}$ protein, which is recognized by specific phagocytic cell CR1 receptors for subsequent intracellular destruction. This work was designed to find out whether pulp fibroblasts produce $\mathrm{C} 3 \mathrm{~b}$ and check its subsequent implication in bacteria phagocytosis. Methods: The expression of $\mathrm{C} 3 \mathrm{~b}$ was investigated in carious and healthy human pulp tissues. To simulate a bacterial infection in vitro, cultured human pulp fibroblasts were stimulated with lipoteichoic acid, and C3b secretion was quantified by an enzyme-linked immunosorbent assay. C3b fixation on bacteria (opsonization) and the inflammatory THP-1 cell complement receptor 1 was studied by immunofluorescence. A gentamycin protection assay was used to check the implication of C 3 b secretion by fibroblasts in bacteria phagocytosis. Results: Pulp cells constitutively express $\mathrm{C} 3 \mathrm{~b}$ in vivo, and cultured pulp fibroblasts produce $\mathrm{C} 3 \mathrm{~b}$. We observed a fixation of this C3b protein on the bacterial surface (opsonization) and the THP-1 CR1 receptor. This recognition leads to a significant increase in bacteria phagocytosis. Conclusions: These results showed that pulp fibroblasts mediate the process of phagocytosis by producing the complement $\mathrm{C} 3 \mathrm{~b}$ protein and opsonizing bacteria. This highlights a significant role of fibroblasts in the dental pulp local regulation of inflammation. (J Endod 2019; $\square: 1-7)$
\end{abstract}

\section{Key Words}

Cariogenic bacteria, carious lesion, dental pulp, inflammation, opsonization, phagocytosis
$D_{c o s}^{\text {und }}$ ring the carious process, cariogenic bacterial infiltration through dentin tubules allows them to reach the dental pulp. Salivary bacteria can also reach the dental pulp after tooth fracture with pulp exposure. Arresting bacterial proliferation and subsequent elimination is a prerequisite to resolve the pulp inflammatory reaction in order to initiate the dentin-pulp regeneration process.

More recently, pulp fibroblasts have been shown to be on the crossroads of inflammation and regeneration because of their capacity to synthesize complement proteins (1), highlighting the central function of these cells in regulating the pulp response to injury. Complement is an efficient immune surveillance system. After its activation, this protein cascade, composed of more than 40 proteins, allows a rapid and amplified response to bacterial stimulation (2). Complement proteins are known to be synthesized by the liver and inflammatory cells, but a recent study has shown that after lipoteichoic acid (LTA) stimulation, pulp fibroblasts secrete functional complement proteins (3). In addition to their functions during the inflammatory reaction, recent data reported the involvement of complement activation in dentin-pulp regeneration (4). Indeed, the complement C3 protein produced by pulp fibroblasts is cleaved to $\mathrm{C} 3 \mathrm{a}$ and $\mathrm{C} 3 \mathrm{~b}$. The soluble $\mathrm{C} 3 \mathrm{a}$ fragment has been shown to be involved in fibroblast proliferation and recruitment as well as stem cell proliferation and mobilization (5). Another protein, C5, can be cleaved to $\mathrm{C} 5 \mathrm{a}$ and $\mathrm{C} 5 \mathrm{~b}$ after complement activation. The soluble $\mathrm{C} 5 \mathrm{a}$ has been shown to be involved in brain-derived neurotrophic factor secretion. Coculture of pulp fibroblasts with human neurons in a microfluidic culture system showed that when pulp fibroblasts were stimulated with LTA (simulating bacterial infection), they guided nerve sprouting toward the LTA-stimulated fibroblasts (6). This $\mathrm{C} 5$ a fragment also has been involved in selectively guiding pulp stem cell migration and their recruitment in a gradient-dependent manner (7). The second cleavage fragment, called $\mathrm{C} 5 \mathrm{~b}$, combines to other complement fragments to form the membrane attack complex (MAC), a lytic pore in the bacteria membrane leading to cell lysis. Indeed, coculture of fibroblasts with cariogenic bacteria has shown that the fibroblasts synthesize MAC proteins, which form a functional MAC complex fixed directly on bacteria membranes leading to their lysis as shown by the bacteria viability test (8). However, the role of the locally produced $\mathrm{C} 3 \mathrm{~b}$ fragment by pulp fibroblasts has not been investigated yet. This fragment is known as an opsonin (9). It opsonizes bacteria,

From the *Aix Marseille University, Centre National de la Recherche Scientifique, Institute of Movement Sciences, Marseille, France; and ${ }^{\dagger}$ Department of Fixed Prosthesis and Implant Prosthodontics, School of Dentistry, Aristotle University of Thessaloniki, Thessaloniki, Greece.

Address requests for reprints to Prof Imad About, Institut des Sciences du Mouvement, UMR 7287 Centre National de la Recherche Scientifique, Université d'AixMarseille Faculté d'Odontologie, 27 BD Jean Moulin, 13385 Marseille, Cedex 5, France. E-mail address: imad.about@univ-amu.fr

0099-2399/\$ - see front matter

Copyright (C) 2019 American Association of Endodontists.

https://doi.org/10.1016/j.joen.2018.10.023 
and it is well established that the opsonization of pathogens leads to a more efficient phagocytosis (10) thanks to the complement receptor 1 (CR1) expression on phagocytic cells. This receptor recognizes $\mathrm{C} 3 \mathrm{~b}$ bound on bacterial membranes leading to their engulfment. CR1 expression has been shown to be increased by tumor necrosis factor alpha, tumor necrosis factor beta, or interleukin 4 (11). The aim of this study was to investigate the involvement of $\mathrm{C} 3 \mathrm{~b}$ produced by pulp fibroblasts in bacteria phagocytosis.

We detected the $\mathrm{C} 3 \mathrm{~b}$ protein in healthy and carious tissues and quantified $\mathrm{C} 3 \mathrm{~b}$ protein secretion by cultured human pulp fibroblasts. Then, we tested the ability of $\mathrm{C} 3 \mathrm{~b}$ to opsonize bacteria and its recognition by the macrophage CR1 receptor. Finally, we studied the impact of $\mathrm{C} 3 \mathrm{~b}$ production by pulp fibroblasts on bacteria engulfment by macrophages.

\section{Reagents}

\section{Materials and Methods}

Cell culture materials and reagents were obtained from Dominique Dutscher (Brumath, France). Complement C3b antibody, CR1 antibody, and secondary antibodies were obtained from Life Technologies (Saint-Aubin, France).

\section{Immunohistochemistry}

Pulps were obtained from human immature third molars freshly extracted for orthodontic reasons in compliance with French legislation; informed patient consent and institutional review board approval of the protocol were obtained. Pulps were fixed and routinely processed as described previously (5). Pulp sections were deparaffinized and rehydrated, and nonspecific binding sites were blocked with $3 \%$ bovine serum albumin in phosphate-buffered saline (PBS). Sections were incubated for 2 hours with mouse immunoglobulin (Ig) $\mathrm{G}$ antihuman $\mathrm{C} 3 \mathrm{~b}(10 \mu \mathrm{g} / \mathrm{mL})$ or an isotype control followed by secondary antibody Alexa Fluor 594 donkey antimouse $\operatorname{IgG}(2.5 \mu \mathrm{g} / \mathrm{mL})$ and counterstained with $1 \mu \mathrm{g} / \mathrm{mL} \mathrm{4}$,6-diamidino-2-phenylindole (DAPI) for 45 minutes. Some sections were stained with hematoxylin-eosin (Sigma-Aldrich, St Louis, MO) according to the manufacturer's instructions.

\section{Bacteria Culture}

Two cariogenic bacteria strains were used: Streptococcus mutans (American Type Culture Collection [ATCC] No. 31383) and Streptococcus sanguinis (ATCC No. BAA-1455). Additionally, 2 strains that can be found in the saliva (12) were used: Enterococcus faecalis (ATCC No. 47077) and Enterococcus faecium (ATCC No. 1943). All bacteria were obtained from ATCC (Manassas, VA) and cultured at $37^{\circ} \mathrm{C}$ in an aerobic condition in Lennox Broth base medium (Life Technologies).

\section{ThP-1 Gell Gulture}

THP-1 cells, a human monocytic cell line (Sigma-Aldrich), were cultured in Roswell Park Memorial Institute medium as described previously. THP-1 cells were activated with $100 \mathrm{ng} / \mathrm{mL}$ phorbol 12-myristate 13-acetate for 48 hours.

\section{Pulp Fibroblast Cell Culture}

Primary pulp cells were prepared from immature third molars by the explant outgrowth method. Pulp fibroblasts were isolated from pulp cell cultures and characterized as previously described $(8,13)$. Pulp fibroblasts were cultured in minimal essential medium supplemented with $10 \%$ fetal bovine serum, L-glutamine $2 \mathrm{mmol} / \mathrm{L}$, penicillin/ streptomycin $50 \mu \mathrm{g} / \mathrm{mL}$, and amphotericin B $0.25 \mu \mathrm{g} / \mathrm{mL}$ at $37^{\circ} \mathrm{C}$ in a $5 \% \mathrm{CO}_{2}$ atmosphere.

\section{Stimulation of Pulp Fibroblasts}

At subconfluence, fibroblasts were incubated with serum-free medium $\pm \mathrm{LTA}$ at $1 \mu \mathrm{g} / \mathrm{mL}$. The fibroblast supernatants were harvested at different incubation periods and used for the following experiments. Serum-free medium was used as the control.

\section{C3b Quantification}

Supernatants were harvested after 5 and 24 hours to determine the C3b concentration using an enzyme-linked immunosorbent assay. Culture plates (Nunc Maxisorp, Dutscher) were coated with human C3b antibodies $(10 \mu \mathrm{g} / \mathrm{mL})$ overnight at $4^{\circ} \mathrm{C}$. Nonspecific binding sites were blocked with 3\% milk in PBS for 1 hour, and then samples and standards of complement $\mathrm{C} 3 \mathrm{~b}$ human protein (Calbiochem; Millipore, Burlington, MA) were incubated at room temperature (RT) for 2 hours. Biotinylated secondary antibody (C3b Biotin-Human antibody; Assaypro, St Charles, MO) was added at $10 \mu \mathrm{g} / \mathrm{mL}$. After 1 hour, horseradish peroxidase conjugate streptavidin (R\&D Systems, Minneapolis, MN) was added and incubated for 20 minutes at RT. Tetramethylbenzidine substrate solution (Life Technologies) was added, and absorbance was measured at $650 \mathrm{~nm}$. All experiments were performed in triplicate with 3 different fibroblast populations (Fig. 1).

\section{C3b Fixation on Bacteria}

Bacteria $\left(10^{9}\right.$ bacteria $\left./ \mathrm{mL}\right)$ were incubated for 1 hour at $37^{\circ} \mathrm{C}$ under agitation in control medium or supernatants \pm LTA. Bacteria were washed with PBS and fixed with a hair dryer on 8-well glass culture chambers. Nonspecific sites were blocked as described earlier, and bacteria were incubated for 2 hours with mouse IgG antihuman C3b $(5 \mu \mathrm{g} / \mathrm{mL})$ or the isotype control at RT followed by 45 minutes with Alexa Fluor 594 antimouse IgG $(2 \mu \mathrm{g} / \mathrm{mL})$ at RT for 45 minutes (Fig. 1).

\section{Colocalization of CR1 Receptor and C3b on Macrophages}

Activated THP-1 cells were grown in 8-well glass culture chambers to $50 \%$ confluency. Cells were incubated with fibroblast supernatants \pm LTA for 1 hour at $37^{\circ} \mathrm{C}$ in $5 \% \mathrm{CO}_{2}$. Cells were fixed with $2 \%$ paraformaldehyde for 15 minutes at $4{ }^{\circ} \mathrm{C}$. Then, nonspecific binding sites were blocked with $1 \%$ bovine serum albumin in PBS for 1 hour at RT. Cells were incubated with mouse IgG antihuman CR1 $(7 \mu \mathrm{g} / \mathrm{mL})$ or the isotype control overnight at $4^{\circ} \mathrm{C}$ followed by secondary antibody Alexa Fluor 488 goat antimouse IgG $(2 \mu \mathrm{g} / \mathrm{mL})$ for 45 minutes. After washing steps in PBS, cells were incubated for 2 hours at RT with mouse IgG antihuman $\mathrm{C} 3 \mathrm{~b}(5 \mu \mathrm{g} / \mathrm{mL})$ or the isotype control followed by secondary Alexa Fluor 594 donkey antimouse $\operatorname{IgG}(2 \mu \mathrm{g} / \mathrm{mL})$ and counterstained with $1 \mu \mathrm{g} / \mathrm{mL}$ DAPI for 45 minutes (Fig. 1).

\section{Gentamycin Protection Assay}

Bacteria ingestion by macrophages was measured using a gentamicin protection assay as described previously (14). Briefly, bacteria $\left(10^{7}\right.$ bacteria/well $)$ were incubated in fibroblast supernatants \pm LTA for 1 hour at $37^{\circ} \mathrm{C}$ under agitation and added to activated THP-1 $\left(10^{5}\right.$ cells/well) for 2 hours. A negative control was performed by adding Cytochalasin D (Sigma-Aldrich) at $10 \mu \mathrm{mol} / \mathrm{mL}$. Extracellular bacteria were killed with $200 \mu \mathrm{g} / \mathrm{mL}$ gentamicin for 1 hour at $37^{\circ} \mathrm{C}$, and intracellular bacteria were released with $0.1 \%$ Triton X-100 (Sigma-Aldrich, St. Louis, MO) for 5 minutes at RT. Intracellular bacteria were diluted, and $100 \mu \mathrm{L}$ was spread across the agar plate surface (Lennox Broth agar; Pronadisa Conda, Madrid, Spain) in triplicate and 


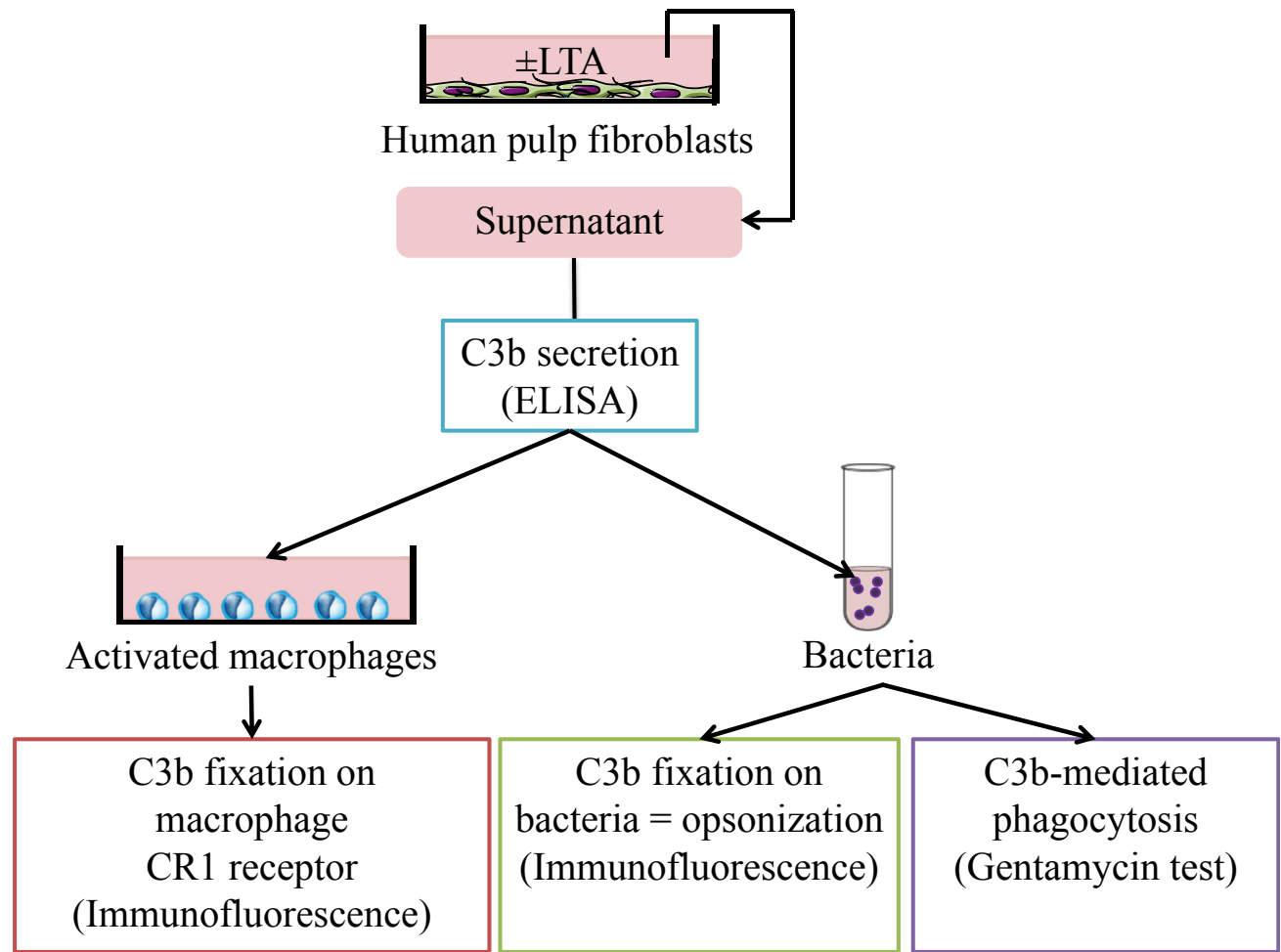

Figure 1. A sketch of the experimental procedure. To simulate bacterial infection, pulp fibroblasts were incubated in serum-free medium \pm LTA. Supernatants were harvested to measure $\mathrm{C} 3 \mathrm{~b}$ using an enzyme-linked immunosorbent assay. C3b produced by pulp fibroblasts was detected on the bacteria surface (opsonization) and on the CR1 macrophage receptor by immunofluorescence. The involvement of C3b produced by pulp fibroblasts in bacteria phagocytosis was analyzed by a gentamycin test.

incubated for 24 to 72 hours at $37^{\circ} \mathrm{C}$. Colonies were counted on agar plates, and the average of the triplicates was established. Results were expressed in colony-forming units (CFUs) per milliliter using the following equation:

$$
\text { CFU per milliliter }=\frac{\text { number of colony } \times \text { dilution factor }}{\text { volume of spread suspension }(\mathrm{mL})}
$$

\section{Statistical Analysis}

All experiments were repeated in triplicate with 3 different cell populations to compare the different treatments and their respective controls. The Student $t$ test was used for statistical analysis. Statistical significance was set at $P<.05$.

\section{Results \\ C3h Expression in the Dental Pulp}

Hematoxylin-eosin staining shows an intact pulp for both healthy (Fig. 2Aa) and carious teeth (Fig. $2 A d$ ). Intense labeling was observed in healthy (Fig. $2 A b$ ) and carious teeth pulp tissues (Fig. $2 A e$ ). No fluorescence was observed in the isotype controls (Fig. $2 A C$ and $2 A f$ ).

\section{C3h Is Produced by Cultured Pulp Fibroblasts}

There is a quick and significant increase of $\mathrm{C} 3 \mathrm{~b}$ release after 5 and 24 hours in fibroblast supernatants (Fig. 2B). The secretion after 24 hours was significantly higher than after 5 hours. No statistically significant difference was obtained with or without LTA stimulation. C3b was not detected in the control, showing the absence of $\mathrm{C} 3 \mathrm{~b}$ protein in the serum-free medium.

\section{C3b Produced by Pulp Fibroblasts Opsonizes Bacteria}

Immunofluorescence images of Streptococcus sanguinis (Fig. 3Aa), Streptococcus mutans (Fig. 3Ab), Enterococcus faecium (Fig. $3 A c$ ), and Enterococcus faecalis (Fig. $3 A d$ ) are shown with their respective phase-contrast pictures (Fig. 3Aa1-Ad1). When grampositive bacteria were incubated with fibroblast supernatants after LTA stimulation, we observed an intense red labeling at the bacterial surface with all strains. Similar bacteria immunofluorescence labeling was obtained with supernatants from unstimulated fibroblasts (data not shown). No fluorescence was detected in the isotype control (Fig. $3 \mathrm{Ae}$ and $\mathrm{Ae} 1$ ).

\section{C3b Produced by Pulp Fibroblasts Is Recognized by Macrophage GR1 Receptor}

When macrophages were incubated with supernatants from unstimulated (Fig. $3 B a-B C$ ) or from LTA-stimulated fibroblasts (Fig. $3 B e-$ $B g$ ), we observed a red fluorescence reflecting $\mathrm{C} 3 \mathrm{~b}$ fixation (Fig. $3 B a$ and $B e$ ) and a green fluorescence reflecting the CR1 receptor expression (Fig. $3 B b$ and $B f$ ) on the macrophage surface. $\mathrm{C} 3 \mathrm{~b}$ protein fixation and CR1 receptor expression on the macrophage surface were colocalized as observed in the merged pictures (Fig. $3 B c$ and $B g$ ). No fluorescence was observed in the isotype control (Fig. $3 B d$ and $B h$ ).

\section{Bacteria Engulfment Is More Efficient with G3b Produced by Pulp Fibroblasts}

To determine whether $\mathrm{C} 3 \mathrm{~b}$ produced by pulp fibroblasts renders bacteria more susceptible to phagocytosis by macrophages, a gentamycin protection assay was performed (Figure $4 A$ ). Macrophages were able to phagocyte the 4 bacterial strains: $S$. sanguinis and $S$. mutans 


\section{Basic Research-Biology}

A
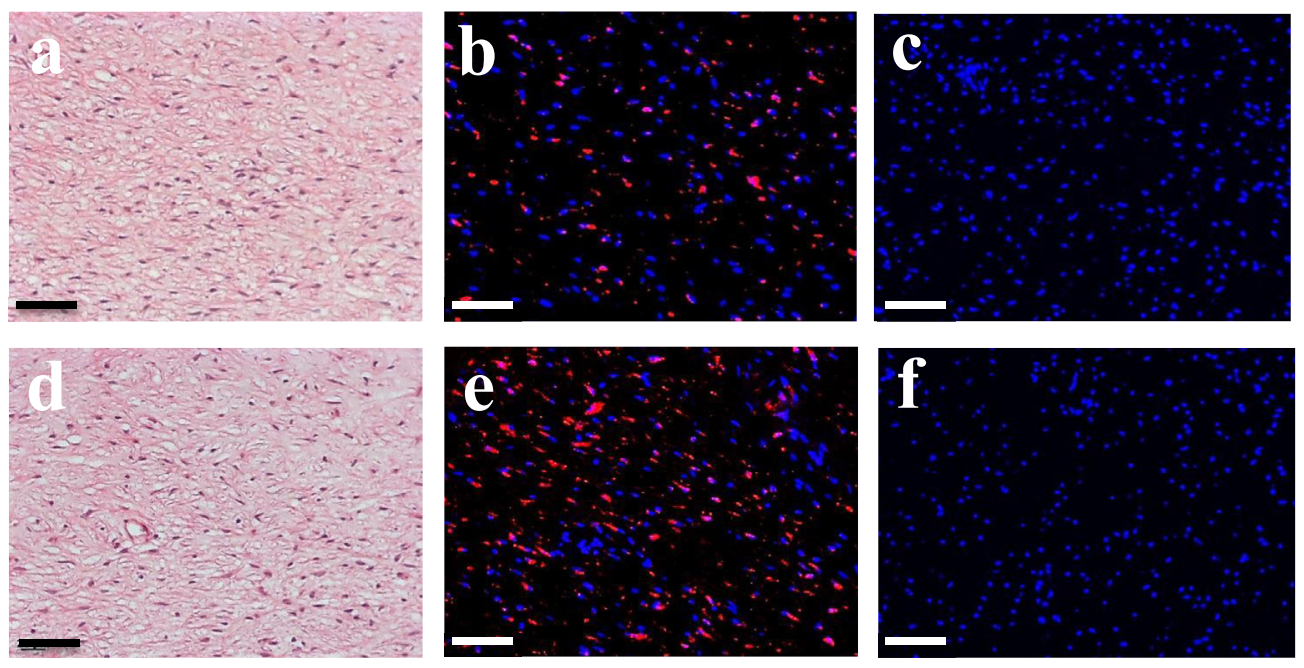

B

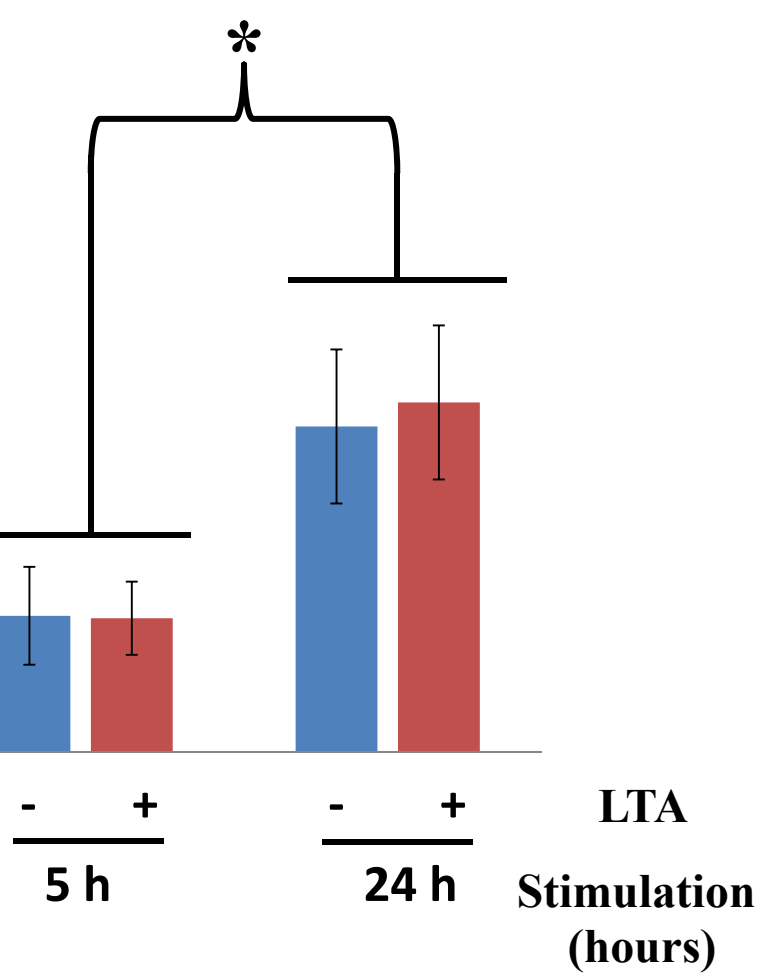

Figure 2. C3b complement protein expression and release. (A) Immunofluorescence of $\mathrm{C} 3 \mathrm{~b}$ expression on healthy and carious teeth pulps. A representative image of hematoxylin-eosin staining of $(A a)$ healthy and $(A d)$ carious teeth pulps. Immunostaining of C3b complement protein $(r e d)$ on $(A b)$ healthy and $(A e)$ carious teeth pulp shows the expression of $\mathrm{C} 3 \mathrm{~b}$ in both. ( $A c$ and $A f)$ Isotype controls, respectively. Nuclei were counterstained with DAPI (blue). Scale bars: $50 \mu \mathrm{m}$. (B) The histogram shows a significant increase of $\mathrm{C} 3 \mathrm{~b}$ secretion in the fibroblast supernatant at 5 and 24 hours with and without LTA stimulation. This secretion at 5 and 24 hours is significantly different from the control. *Indicate significant differences between the 2 conditions $(P<.05)$. Bars represent the means \pm standard errors of the mean $(n=3)$.

(Fig. $4 B a$ ) and $E$. faecalis and $E$. faecium (Fig. $4 B b$ ) in serum-free medium. However, when bacteria were incubated with fibroblast supernatants, we observed a significant increase of intracellular bacteria, reflecting an increase of phagocytosis. A statistically significant difference was observed between $S$. sanguinis/S. mutans and $E$. faecalis/ E. faecium as reflected by the different scales on the y-axis. No significant differences were observed between phagocytosis in the presence of fibroblast supernatants \pm LTA. When Cytochalasin D, an inhibitor of
F-actin-dependent phagocytosis, was added, no CFUs were detected, indicating that the counted bacteria were only intracellular and engulfed by phagocytosis.

\section{Discussion}

The main outcome of this study is that pulp fibroblasts constitutively express and secrete the complement $\mathrm{C} 3 \mathrm{~b}$ fragment. The released 
Basic Research-Biology

A
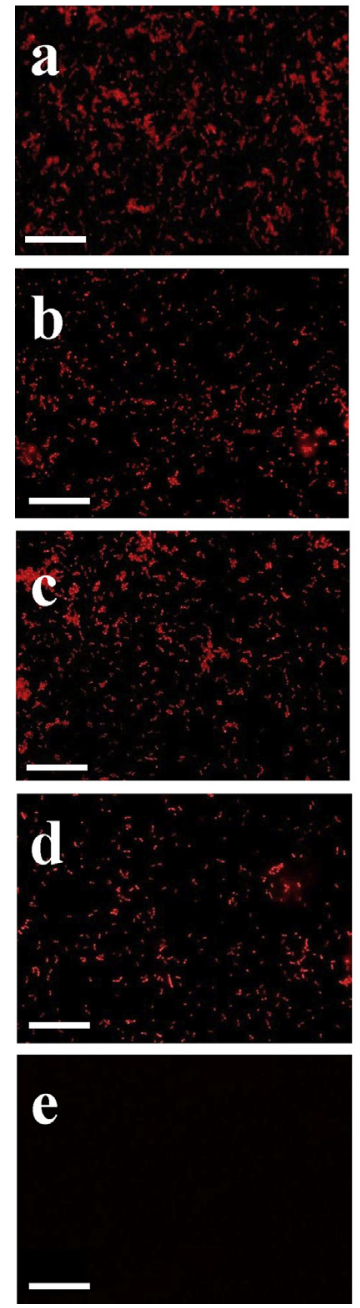

B
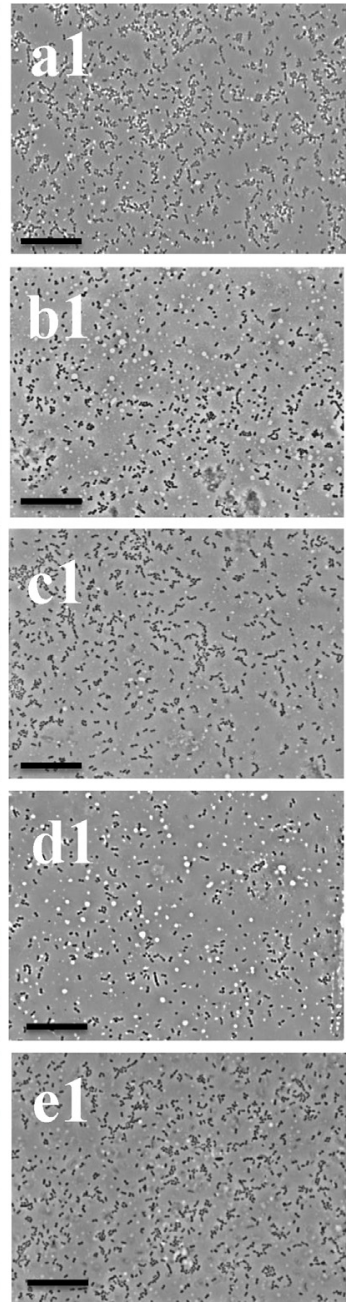

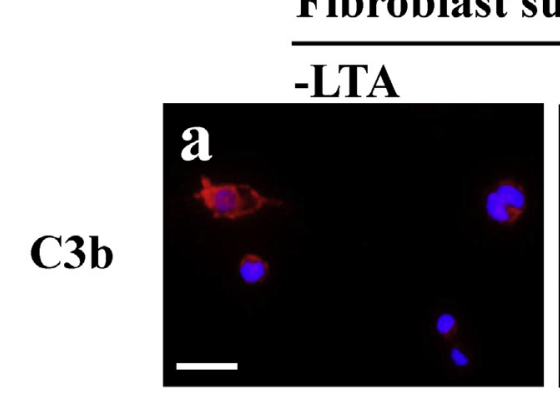

Fibroblast supernatants
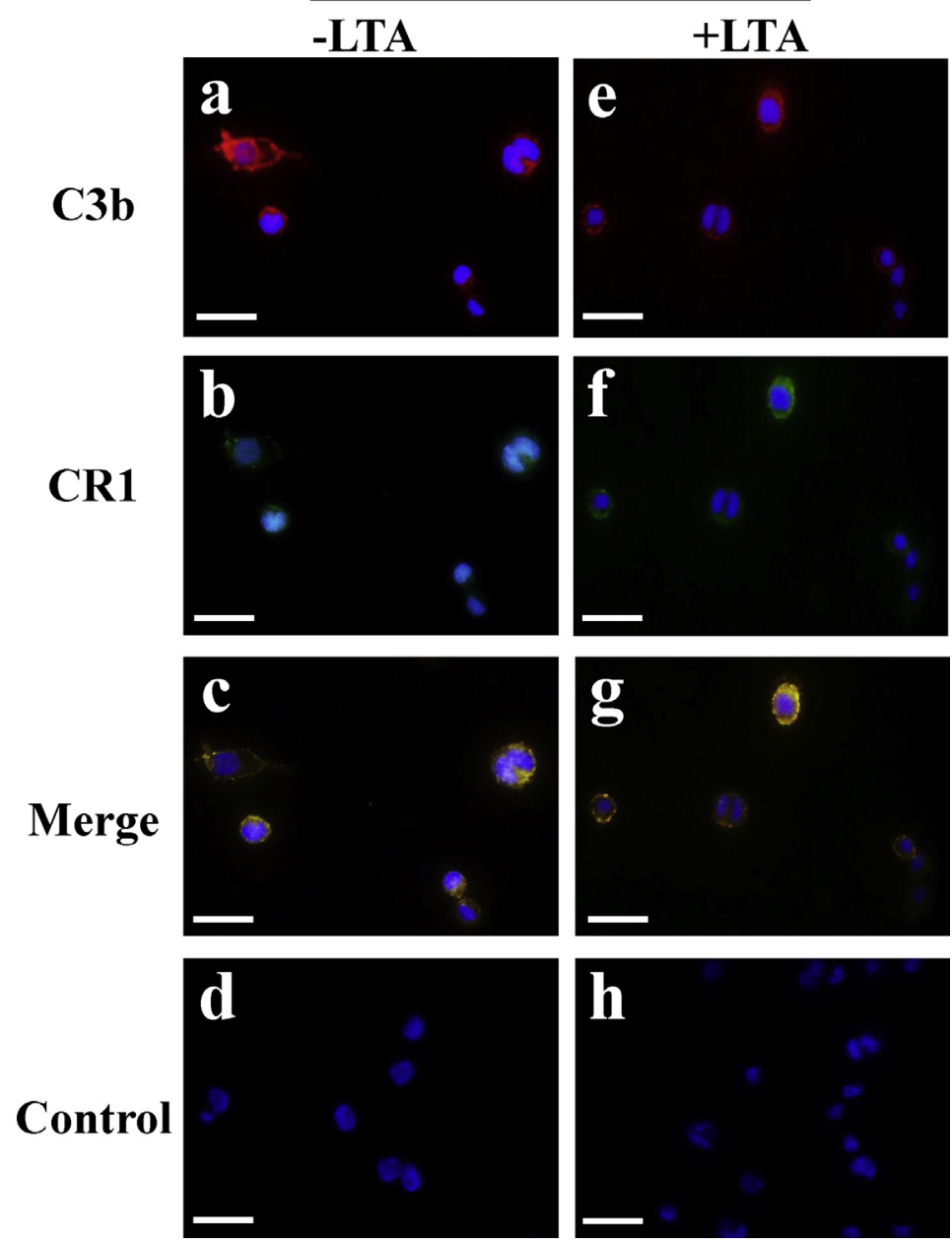

Figure 3. C3b opsonization of bacteria and its recognition by macrophage CR1 receptors. (A) Bacteria opsonization is shown by C3b fixation on their surface. This figure shows immunostaining of C3b protein (red) on the surface of (a) S. sanguinis, (b) S. mutans, (c) E. faecium, and (d) E. faecalis after their incubation with fibroblast supernatant with LTA and their $(a 1-d 1)$ respective phase-contrast pictures. (e) The isotype control on $S$. mutans and $(e 1)$ its respective phase-contrast image. Scale bars: $20 \mu \mathrm{m}$. $(B)$ Immunofluorescence shows $(a$ and $e$ ) C3b protein and $(b$ and $f)$ CR1 receptor expression on macrophages incubated with fibroblast supernatant without and with LTA, respectively. $c$ and $g$ are merge images of C3b and CR1 with fibroblast supernatant without and with LTA, respectively. This shows that $\mathrm{C} 3 \mathrm{~b}$ is recognized by macrophage CR1 receptor. Nuclei were counterstained with DAPI (blue). $d$ and $b$ are isotype controls. Scale bars: $20 \mu \mathrm{m}$.

fragment is fixed on bacteria and recognized by its CR1 receptor on the macrophages. This fixation is followed by stimulation of bacteria engulfment.

Indeed, C3b protein detection on human healthy pulp sections reveals a constitutive $\mathrm{C} 3 \mathrm{~b}$ expression. This is further confirmed by the release of this fragment from cultured pulp fibroblasts. The release of this fragment was found to increase in function of time whether the fibroblasts were stimulated with LTA or not. This shows a readyto-go local regulation potential for gram-positive bacteria opsonization even before any bacterial invasion of the dental pulp. Although cariogenic bacteria are mainly gram positive, it remains to be established whether pulp fibroblasts can also be stimulated by lipopolysaccharides of gram-negative bacteria.

Immunofluorescence revealed that the $\mathrm{C} 3 \mathrm{~b}$ produced by pulp fibroblasts with or without LTA stimulation opsonizes different bacteria. This C3b fixation on bacteria was rapid because all studied bacteria were opsonized within an hour of incubation. This result shows that the $\mathrm{C} 3 \mathrm{~b}$ constitutively produced by pulp fibroblasts is bioactive and represents an immune surveillance system within the dental pulp.

Colabeling experiments of both $\mathrm{C} 3 \mathrm{~b}$ released in fibroblast supernatants and macrophage $\mathrm{CR} 1$ receptor showed a colocalization of both proteins on the macrophage membrane, indicating that $\mathrm{C} 3 \mathrm{~b}$ protein is recognized by the macrophage by binding to its CR1 receptor. This demonstrates that the $\mathrm{C} 3 \mathrm{~b}$ fragment synthesized by fibroblasts opsonizes bacteria and binds to its CR1 receptor on the macrophage membranes. Pulp fibroblasts stimulated or not by LTA produce the same level of $\mathrm{C} 3 \mathrm{~b}$. Immunofluorescence showed that the $\mathrm{C} 3 \mathrm{~b}$ protein can opsonize bacteria in both conditions and can be recognized by CR1 receptor on THP-1.

Next, we checked if bacteria opsonized with $\mathrm{C} 3 \mathrm{~b}$ and recognized by the macrophage CR1 receptor would lead to a stimulation of their ingestion. For this purpose, we used macrophages as phagocytic cells because macrophages are considered as the major immunocompetent cells in the dental pulp (15). Additionally, we used an original culture system of macrophages directly incubated with C3b-opsonized bacteria 


\section{Basic Research-Biology}

A
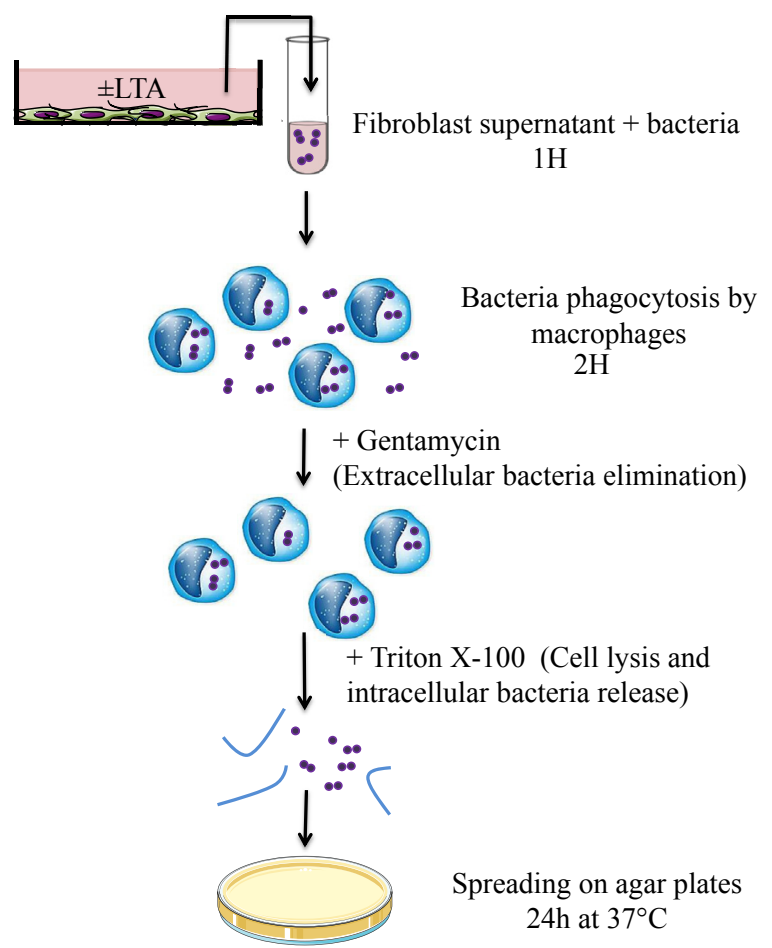

Spreading on agar plates $24 \mathrm{~h}$ at $37^{\circ} \mathrm{C}$

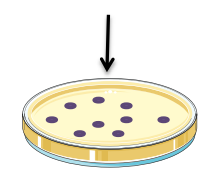

B

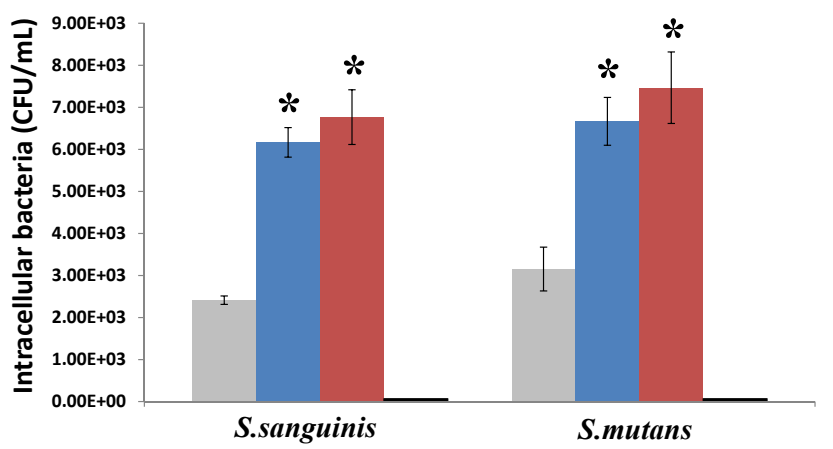

b

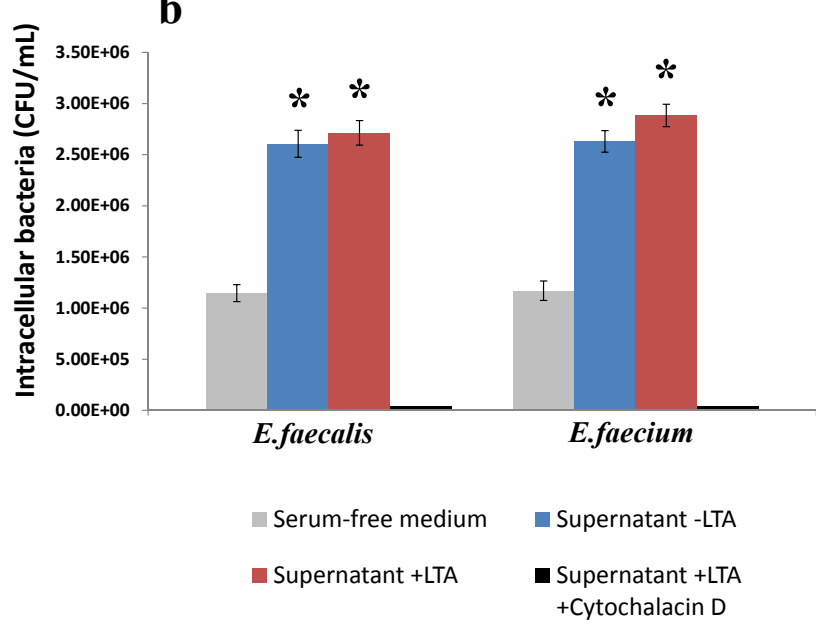

Figure 4. Quantification of phagocytosed bacteria: gentamycin protection assay. (A) A schematic illustration of the gentamycin protection assay. (B) The viable intracellular bacteria count with the gentamycin protection assay. Macrophages were incubated with (Ba) $S$. sanguinis and $S$. mutans and (Bb) E. faecalis and $E$. faecium. No viable intracellular bacteria were observed when macrophages were treated with Cytochalasin D, indicating the absence of phagocytosis. There was a statistically significant increase $(*)$ in the number of viable bacteria in fibroblast supernatants compared with the serum-free control. There was a statistically significant difference in the number of viable bacteria between $S$. sanguinis/S. mutans on one side and $E$. faecalis/E. faecium on the other side as reflected by different scales on the y-axis. Bars represent mean values \pm standard error of the mean $(n=3)(* P<.05)$.

called the gentamicin protection assay. This system not only allows us to check bacteria phagocytosis but also to quantify the viable intracellular (engulfed) bacteria. It should be pointed out that phagocytic cells recognize pathogens by 2 mechanisms. The first one is mediated by the pathogen-associated molecular patterns (PAMPs), which can be recognized by phagocytic cell pattern recognition receptors (PRRs). Previous studies have reported that cariogenic bacteria phagocytosis by inflammatory cells via PAMP/PRR recognition occurs in the dental pulp (16). Not surprisingly, engulfment of bacteria was also obtained in our investigation when bacteria were incubated with macrophages in serum-free medium.

The second mechanism of pathogen recognition by phagocytic cells is mediated by opsonins such as $\mathrm{C} 3 \mathrm{~b}$, which binds to pathogens in a nonspecific manner. It is well-known that pathogen opsonization leads to more efficient phagocytosis $(17,18)$.

The gentamycin test clearly showed that fibroblast supernatants significantly increased the quantity of intracellular bacteria engulfed by the macrophages, reflecting a significant increase of phagocytosis that was inhibited when Cytochalasin D was added. This increase with fibroblast supernatants was significant when compared with phagocytosis serum-free medium. Indeed, the phagocytosis of bacteria in the serum-free medium is mediated by PAMP/PRR recognition whereas that in fibroblast supernatants \pm LTA is mediated both by PAMP/PRR and $\mathrm{C} 3 \mathrm{~b} / \mathrm{CR} 1$ recognition pathways. Moreover, recent studies revealed an important synergistic interaction between the 2 mechanisms in the overall phagocytosis outcome (19). Thus, although we cannot exclude the effect of other soluble factors secreted by fibroblasts, our results strongly suggest a role of $\mathrm{C} 3 \mathrm{~b}$ synthetized by fibroblasts in the enhancement of bacteria phagocytosis. When comparing the number of engulfed bacteria, major differences were observed among the studied strains. The number of engulfed $E$. faecalis and $E$. faecium was significantly higher than that of $S$. mutans and $S$. sanguinis, which showed comparable results. Although our investigation cannot provide a clear explanation to the differences among the rates of bacteria engulfment, this can be partially explained by the fact that $S$. mutans and $S$. sanguinis may have a phagocytosis resistance system. It has been shown for example that $S$. mutans has a hydrophobic polysaccharide dextran capsule leading to phagocytosis resistance (20).

Overall, in addition to their involvement in macrophage recruitment (4), complement proteins produced by pulp fibroblasts have been shown to be involved in direct bacteria destruction via MAC formation (8). This work adds to our understanding that $\mathrm{C} 3 \mathrm{~b}$ produced by fibroblasts leads to cariogenic bacteria opsonization and phagocytosis as shown with $S$. mutans and $S$. sanguinis. In addition to cariogenic bacteria, our investigation shows that this immune surveillance is efficient against other bacteria such as $E$. faecalis and $E$. faecium that 
may reach the pulp from saliva after tooth fracture with pulp exposure. This antibacterial activity may be responsible in part of the pulp survival after traumatic injury with pulp exposure (21). Dentin pulp regeneration can take place only if cariogenic bacterial infection is controlled. Although bioactive complement components produced by pulp fibroblasts such as $\mathrm{C5a}, \mathrm{C} 3 \mathrm{a}$, and MAC were investigated, 2 molecules were not studied yet: $\mathrm{C} 3 \mathrm{~b}$ and $\mathrm{C} 5 \mathrm{~b}$. Indeed, $\mathrm{C} 3 \mathrm{a}$ and $\mathrm{C} 5 \mathrm{a}$ have been shown to be involved in the initial steps of pulp regeneration. In addition to MAC, we report here on $\mathrm{C} 3 \mathrm{~b}$ function in pulp inflammation control. Exploring other complement protein functions such as that of $\mathrm{C} 5 \mathrm{~b}$ needs to be investigated in a future work. Also, this research highlights the significant role of pulp fibroblasts in the local regulation of pulp inflammation, which is a prerequisite for pulp regeneration. A better understanding of the mechanisms of cariogenic bacteria elimination would allow developing new therapeutic agents to treat carious injuries and target pulp inflammation.

\section{Acknowledgments} teeth.

The authors thank Dr Jean-Charles Gardon for providing the

Supported by Aix-Marseille University and CNRS.

The authors deny any conflicts of interest related to this study.

\section{References}

1. Jeanneau C, Lundy FT, El Karim IA, et al. Potential therapeutic strategy of targeting pulp fibroblasts in dentin-pulp regeneration. J Endod 2017;43:17-24.

2. Ricklin D, Hajishengallis G, Yang K, et al. Complement: a key system for immune surveillance and homeostasis. Nat Immunol 2010;1:785-97.

3. Chmilewsky F, Jeanneau C, Laurent P, et al. Pulp fibroblasts synthesize functional complement proteins involved in initiating dentin-pulp regeneration. Am J Pathol 2014:184:1991-2000.

4. Giraud T, Rufas P, Chmilewsky F, et al. Complement activation by pulp capping materials plays a significant role in both inflammatory and pulp stem cells' recruitment. J Endod 2017;43:1104-10.
5. Rufas P, Jeanneau C, Rombouts C, et al. Complement C3a mobilizes dental pulp stem cells and specifically guides pulp fibroblast recruitment. J Endod 2016;42: 1377-84.

6. Chmilewsky F, About I, Chung S-H. Pulp fibroblasts control nerve regeneration through complement activation. J Dent Res 2016;95:913-22.

7. Chmilewsky F, Jeanneau C, Laurent P, et al. Pulp progenitor cell recruitment is selectively guided by a C5a gradient. J Dent Res 2013;92:532-9.

8. Jeanneau C, Rufas P, Rombouts C, et al. Can pulp fibroblasts kill cariogenic bacteria? Role of complement activation. J Dent Res 2015;94:1765-72.

9. Underhill DM, Ozinsky A. Phagocytosis of microbes: complexity in action. Annu Rev Immunol 2002;20:825-52.

10. Cunnion KM, Zhang H-M, Frank MM. Availability of complement bound to Staphylococcus aureus to interact with membrane complement receptors influences efficiency of phagocytosis. Infect Immun 2003;72:656-62.

11. Liu D, Niu Z-X. The structure, genetic polymorphisms, expression and biological functions of complement receptor type 1 (CR1/CD35). Immunopharmacol Immunotoxicol 2009:31:524-35.

12. Komiyama EY, Lepesqueur LS, Yassuda CG, et al. Enterococcus species in the oral cavity: prevalence, virulence factors and antimicrobial susceptibility. PLoS One 2016;11:102-12.

13. Chmilewsky F, Jeanneau C, Dejou J, et al. Sources of dentin-pulp regeneration signals and their modulation by the local microenvironment. J Endod 2014;40: S19-25.

14. Laroux FS, Romero X, Wetzler L, et al. Cutting edge: MyD88 controls phagocyte NADPH oxidase function and killing of gram-negative bacteria. J Immunol 2005; 175:5596-600.

15. Farges J-C, Alliot-Licht B, Renard E, et al. Dental pulp defence and repair mechanisms in dental caries. Mediators Inflamm 2015;2015:1-16.

16. Jang J-H, Shin HW, Lee JM, et al. An overview of pathogen recognition receptors for innate immunity in dental pulp. Mediators Inflamm 2015;2015: $1-12$.

17. Aderem A, Underhill DM. Mechanisms of phagocytosis in macrophages. Annu Rev Immunol 1999;17:593-623.

18. Hiemstra PS, Daha MR. Opsonization. Encyclopedia of Immunology. Philadelphia, PA: Elsevier; 1998:1885-8.

19. Hajishengallis G, Lambris JD. Crosstalk pathways between Toll-like receptors and the complement system. Trends Immunol 2010;31:154-63.

20. Tsuda H, Yamashita Y, Toyoshima K, et al. Role of serotype-specific polysaccharide in the resistance of Streptococcus mutans to phagocytosis by human polymorphonuclear leukocytes. Infect Immun 2000;68:644-50.

21. Borkar S, Ataide I. Biodentine pulpotomy several davs after pulp exposure: four case reports. J Conserv Dent 2015;18:73. 